\title{
The Need for Economic Policy Coordination Between Europe, Japan, and the United States: Policy Recommendations for the 1990s
}

\author{
ANTHONIE KNOESTER \\ Erasmus University Rotterdam, Netherlands \\ ANDRÉ KOLODZIEJAK \\ University of Nijmegen, Netherlands
}

Key words: International policy coordination, OECD fiscal policies, trade imbalances, economic growth, inverted Haavelmo effect, wage moderation

\begin{abstract}
Better policy coordination between Europe, Japan, and the United States is urgently needed in order to restore economic growth and to diminish mutual trade imbalances. Using the EC Compact model it is shown how coordinated fiscal policies can contribute to reaching these goals in the 1990s. For Europe, the most plausible fiscal policy option seems to be a combination of lower direct taxes, public spending cuts, and wage moderation; for Japan a more expansionary fiscal policy is feasible. For the United States, however, public spending cuts or tax increases are necessary conditions for better economic performance. In addition, for all three blocks a swap between tax reduction and wage moderation is recommended.
\end{abstract}

In a recent lecture, Yoshio Okawara (1991) said that the major countries of the world-i.e., Europe, Japan, and the United States-should share responsibility and the burden for maintaining the peace and welfare of all nations, including those under different political systems. In this respect Okawara mentioned as a first area on which the joint efforts should focus the issue that ". . . a substantial amount of trade imbalance is feared to remain between Japan and the United States in the years ahead."' The fear of sustained substantial trade imbalances is certainly not a specific American-Japanese problem. It is also a question of great concern for the future relations between Japan and the European Community $(E C)$. In a speech (1991) at the fifth annual EC-Japan journalists' Conference in Osaka, European Commission Vice-President Frans Andriessen said: ". . . we remain very concerned by the important and persisting deficit of the trade pattern between the EC and Japan. According to the most recent Japanese figures, that deficit deteriorated from 18.4 billion U.S. dollars to over 23 billion U.S. dollars in the first 10 months of $1991 \ldots$. If the economic forecasters are right, Japan will continue to generate large current account surpluses through the 1990s." And according 
to Dries van Agt (1990), former EC ambassador to Japan and the present EC ambassador to the United States, " . . . relations between the Community and Japan are less strained than transpacific ones, though many of the problems tackled by the Americans are ours as well. Our trade deficit with Japan is \$24 billion now, half of the American deficit with that country, but nonetheless unacceptably huge. . . It is worth noting in this context that presently the United States and the Community are almost on balance in their bilateral trade."

We quite agree with Okawara (1991) that in avoiding sustained trade imbalances “ . . . any protectionist attempts such as managed trade should be blocked at any costs. Both sides should make utmost efforts to solve problems through rational and practical talks and by not allowing economic problems arising from these imbalances to develop into serious political issues." Apart from possible serious political problems, the threat of increasing protectionism or volatile exchange rate fluctuations between the European, American, and Japanese currencies is reason enough to look for proper ways to find a solution for these trade imbalances. In this article we will not discuss the question as to what extent a further reduction in trade barriers may contribute to this issue. Nor will we discuss exchange rate policies, because Japanese export prices fall when the yen appreciates, as Hooper and Marquez (1993) have noted. We will focus on the question as to how a better coordination of macroeconomic policies between Europe, the United States, and Japan can contribute to fewer trade imbalances. In discussing such international policy coordination, not only the issue of diminishing structural trade imbalances is at stake. At the same time one should keep in mind that, in the 1970s and 1980s, economic growth slowed down drastically in Europe, Japan, and the United States compared with the annual growth rates obtained before the first oil crisis of 1973-1974. Medium- and long-term forecasts of various international organizations point to substantially lower future growth rates compared with the growth rates of the golden 1960s. Recently, this has resulted in a "Declaration on Cooperation for Sustained Global Expansion" that was adopted at the conclusion of the 40th meeting of the Interim Committee of the Board of Governors of the International Monetary Fund in order "to strengthen growth prospects" (IMF 1993). Thus the goal of a reduction in international trade imbalances should be combined with the aim of restoring economic growth in the world's dominant economic blocks. At the same time deficit adjustment should be taken into account, but not at the expense of lower global output, as Currie and Whitley (1993) presume.

In analyzing these global targets of economic policy one should be aware that the world economy has become more interconnected over the past quarter century and that national economies have grown so interdependent as to make economic disturbances readily transmittable (see, e.g., Cooper 1985, OECD 1987, Fieleke 1988, Ghosh and Masson 1993). Obviously, policies to diminish trade imbalances and to restore economic growth in Europe, Japan, and the United States cannot be seen as purely domestic. ${ }^{2}$ Every such policy has important effects on the others and policy actions taken in one block should be prevented from harming the economic policy targets of the other blocks, making the total effect on the three blocks counter-productive. This requires a measure of policy coordination 
between the three blocks on the basis of their own specific economic starting positions. This does not mean we are disregarding the coordination critique of, for example, Vaubel (1983), Feldstein (1987, 1988), and Frankel and Rockett (1988). Our view on the need for macroeconomic policy coordination and its potential benefits is presented in Kolodziejak (1986); Knoester, Kolodziejak, and Muijzers (1989, 1990); and in Knoester and Kolodziejak (1992).

The interdependent global economic system quickly outgrows analytical treatment, so that the questions raised can be consistently analyzed only by using a simulation framework containing both domestic and international dynamic economic interactions. The pioneering work done by Schouten (1964); Johnson and Klein (1974); Oudiz and Sachs (1984); Frankel (1988); McKibbin and Sachs (1988); Canzoneri and Minford (1988); Frenkel, Goldstein, and Masson (1989); and others has demonstrated the usefulness of such an approach which, unlike the traditional Fleming-Mundell approach, also takes into account longer-term dynamic processes. In this article we will use the Compact model, developed by the European Commission's Directorate-General for Economic and Financial Affairs. This is a world model consisting of three interacting blocks (Europe, Japan, and the United States) facing the rest of the world economy.

In Section 1 we shall briefly discuss past economic developments and mediumand long-term forecasts for Europe, Japan, and the United States. In Section 2 we will introduce the main tool of analysis for the said international policy coordination viz. the said multicountry Compact model. This section further contains a comparison of Compact's fiscal multipliers with those of other models, as well as a brief outline of the principle of the inverted Haavelmo effect. In Section 3 different types of fiscal policy will be quantified on the assumption that Europe, Japan, and the United States will act on a purely individual basis. Special emphasis is given to the combination of a tax reduction and wage moderation in order to improve the individual competitive position through a strengthening of the supply-side of the economy. Section 4 discusses the need for economic policy coordination between Europe, Japan, and the United States with special emphasis on how to diminish mutual trade imbalances and how to restore economic growth, and Section 5 contains concluding remarks. We will use the term Europe throughout the text as a shortcut expression for the Community of 12 EC-Member States, unless it is clear from the context that the Community of six is meant (before 1973).

\section{Facts and forecasts}

In Europe, Japan, and the United States economic growth was buoyant in the 1960-1973 period, with Japan outperforming the other two areas with average annual growth rates of almost $10 \%$. For Europe the average was $5 \%$ and for the United States nearly $4 \%$. After the first oil crisis, growth rates dropped substantially in all three blocks, falling to about 3.5\% a year in Japan over the 1974-1982 period, and in Europe and the United States to between 1.5\% and 2\% a year. Table 1 shows that in Europe and the United States annual economic growth improved 


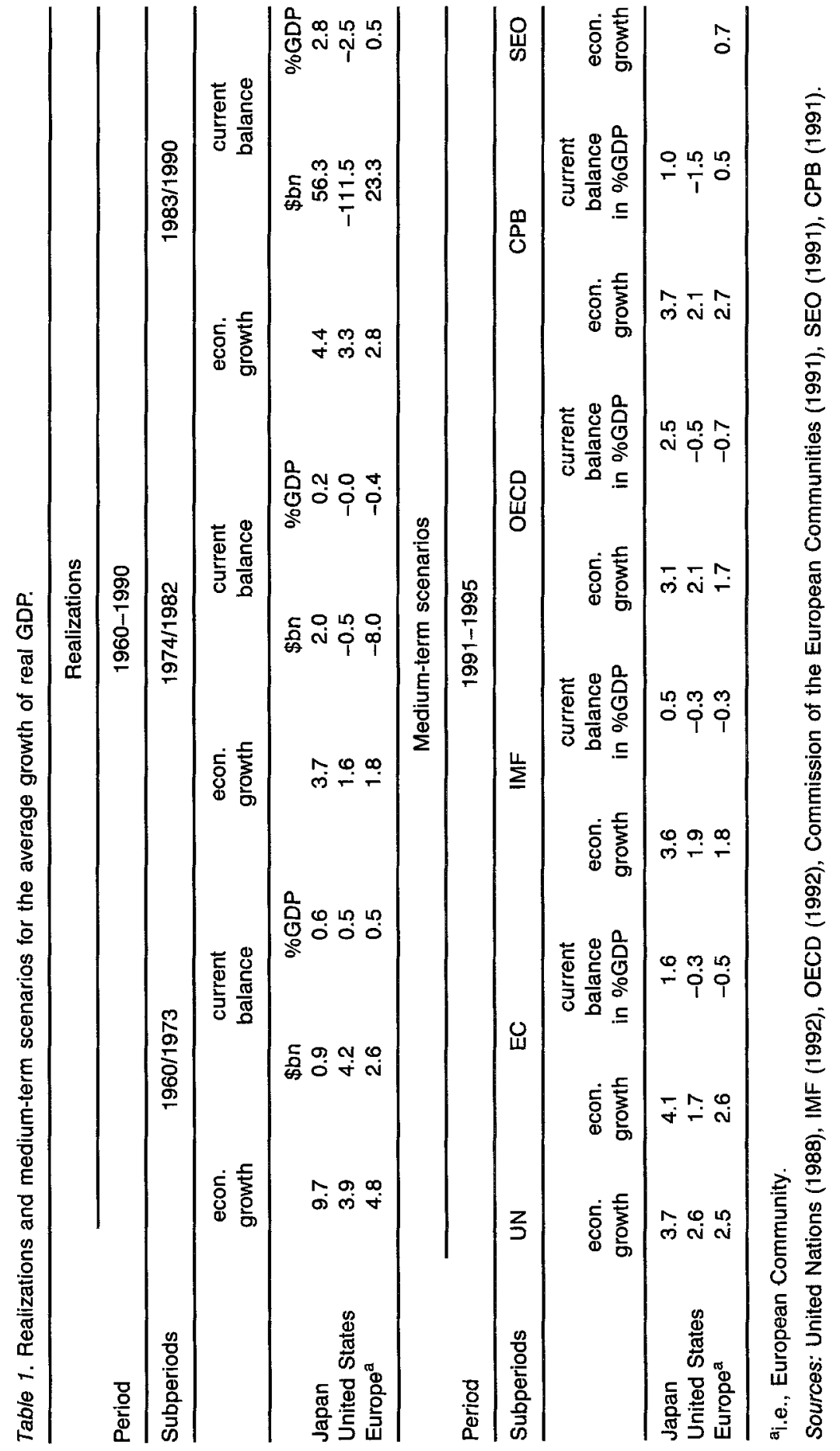


in the 1983-1991 period. Although rather outstanding in the United States, the improvement has been more modest in Europe, whereas in Japan average growth increased further compared with the level of the 1974-1982 period. Medium-term scenarios developed by the International Monetary Fund (IMF), the United Nations, the Organization for Economic Cooperation and Development (OECD), the European Community, and the Dutch Central Planning Bureau (CPB) suggest that, compared with the 1983-1990 period, in the 1991-1995 period growth will slow in the United States, as well as in Japan and Europe. The weighted average slowdown amounts to about $0.8 \%$ points compared with the 1983-1990 period, and to about $3 \%$ points compared with the 1960-1973 figures. On the whole, these mediumterm scenarios foreshadow relatively modest growth rates. Even the highest growth scenarios predict substantially lower growth than before the first oil crisis of 1973 . Table 1 also suggests that the surpluses on the Japanese current account of the balance of payments are approximately equal to the sum of the forecasted trade deficits of the United States and Europe.

Table 2. Long-term scenarios for the average growth rate of real GDP.

\begin{tabular}{lccc}
\hline & Japan & United States & Europe ${ }^{\text {a }}$ \\
\hline $\begin{array}{l}\text { Realizations } \\
1960-1973\end{array}$ & 9.7 & 3.9 & 4.8 \\
\hline $1974-1990$ & 4.0 & 2.4 & 2.4 \\
\hline Forecasts & & & \\
1991-2000 & & & \\
OECD-A & & 3.4 & \\
OECD-B2 & & 4.3 & \\
MIT 1 & & 3.7 & \\
MIT 2 & & 2.5 & 2.5 \\
LEONTIEF CIX & & 3.6 & 3.7 \\
WB-L & & 2.5 & 2.5 \\
WB-H & & 4.3 & 2.6 \\
& & & 2.8 \\
UN-B & 3.8 & 2.6 & 4.3 \\
UN-H & 4.3 & 3.5 & 2.6 \\
CGM-P & 3.3 & 2.9 & 2.7 \\
CGM-B & 3.7 & 3.2 & \\
CGM-O & 4.0 & 3.4 & \\
T-FAIS IV & 4.0 & 3.8 & \\
FUGI-B & 4.1 & 2.5 & \\
WZB-GLOBUS & 3.6 & 3.0 & \\
\hline
\end{tabular}

i.e., European Community.

bweighted average growth rate for total OECD-area or industrial world.

Sources: OECD-A, OECD-B2 from OECD (1979); MIT 1, MIT 2 from MIT (1977); LEONTIEF C/X from LEONTIEF et al. (1977); WB-L, WB-H from World Bank (1987); UN-B, UN-H from United Nations (1988); CGM-P, CGM-B, CGM-O from Centre for Global Modeling, Onishi (1986); T-FAIS IV from University of Tsukuba-Foundation for Advancement of International Science, Shishido (1983); FUGI-B from Onishi (1988); WZB-GLOBUS from Bremer (1987) and ten Brink (1988). 
Table 2 shows several long-term growth scenarios for the 1991-2000 period. For the three blocks together, expeced economic growth varies between average rates of $2.5 \%$ and $4.3 \%$ a year. As for the individual blocks, Japan is expected to have the highest growth rates, whereas the European and American growth rates will be about the same, at a lower rate. The long-term growth scenarios show the same tendencies as the medium-term ones. Here again the anticipated growth rates are substantially below the 1960-1973 ones, although slightly higher than in the 1974-1990 period. Table 3 surveys the past bilateral trade imbalances among Japan, the United States, and Europe. This table makes perfectly clear how in the 1980 s the surpluses of the Japanese trade balance accelerated and are reflected in corresponding trade deficits in the United States and Europe. The table also confirms the statement by Van Agt (1990) that Europe's bilateral trade deficit with Japan is about half the American deficit. The data, in essence, justify the need for improved economic policy coordination among the three blocks.

Table 3. Japanese bilateral trade balance with the United States and Europe (\$ billions).

\begin{tabular}{lccc}
\hline & $\begin{array}{c}\text { Total Japanese } \\
\text { Trade Balance }\end{array}$ & $\begin{array}{c}\text { Bilateral Trade Balance } \\
\text { with the United States }\end{array}$ & $\begin{array}{c}\text { Bilateral Trade Balance } \\
\text { with Europe }\end{array}$ \\
\hline 1976 & 2.42 & 3.88 & 3.61 \\
1977 & 9.69 & 7.32 & 4.54 \\
1978 & 18.20 & 10.13 & 5.03 \\
1979 & -7.64 & 5.97 & 5.10 \\
1980 & -10.72 & 6.96 & 8.81 \\
1981 & 8.74 & 13.31 & 10.34 \\
1982 & 6.90 & 12.15 & 9.50 \\
1983 & 20.53 & 18.18 & 10.40 \\
1984 & 33.61 & 33.08 & 10.07 \\
1985 & 46.10 & 39.49 & 11.12 \\
1986 & 82.74 & 51.40 & 16.69 \\
1987 & 79.71 & 52.09 & 20.02 \\
1988 & 77.56 & 47.60 & 22.80 \\
1989 & 64.96 & 45.70 & 19.85 \\
1990 & 52.37 & 38.28 & 18.71 \\
1991 & 78.26 & 38.57 & 27.64 \\
1992 & 107.04 & 44.02 & 31.50 \\
1993 & 128.23 & 52.82 & 37.80 \\
\hline
\end{tabular}

Source: Keizai Koho Center (1989), IMF (1993a); figures for 1993 are estimates based on realizations in the first quarter of that year.

\section{An overview of the EC Compact world model}

Compact, the macroeconomic model for the world economy, was developed in 1985 by the European Commission's Directorate-General for Economic and Financial Affairs. Since then it has been frequently used in the Commission Services' medium-term analyses. The first version of the model was described in Dramais 
(1986) and new developments in Dramais $(1987) \cdot{ }^{3}$ In essence, the world economy consists of the behavioral models for Europe, the United States, and Japan, interacting against the rest-of-world block, which is mainly a residual item to ensure world accounting consistency for international trade and capital flows. ${ }^{4}$ The European module includes all the basic elements of an operational model:

- a final demand block

- a production and factor demand block

- a wage and price block

- a public-sector block

- a monetary block

- a linkage and balance-of-payments block ${ }^{5}$

Given its relatively small size, the model is used as a testing ground for some new developments in applied econometrics. It should also be understood that the European Community as a homogeneous unit is but a temporary experiment. Leaving aside trade linkage, the EC module includes 50 endogenous variables determined by 28 behavioral equations and 22 identities. The U.S. and Japanese modules were constructed from the structure contained in the Japanese government's Economic Planning Agency (EPA). These two modules were compacted from 18-70 behavioral equations, the coefficients of which are combinations of the original parameters. The rest-of-world module includes only international trade and capital variables, and an estimate of GDP, as computed in the 1983 LINK model. In this module, current and capital account balances are determined to ensure world consistency, that is, to ensure that current and capital world balances sum to zero. The linkage equations allocate imports among the four zones and compute dollar import prices as the weighted average of dollar export from the four zones. Following Dramais (1986), the basic structure of Compact can be summarized as follows:

1. The model takes into account both stock and flow equilibrium by means of a "flow of funds matrix";

2. Wealth effects play a role in the determination of private consumption;

3. Total unemployment is divided into classical, Keynesian, and frictional unemployment according to a disequilibrium approach of the labor market;

4. The difference between Keynesian and classical unemployment plays also a role in the wage and price determination process;

5. The balance of payments is linked to the government budget deficit and the money supply;

6. The exchange rate is influenced by the current and capital accounts and floatsreserves are a constant ratio of imports.

In general, Compact describes fairly well the economic performance of the EC in the 1973-1985 period. The Compact model, as described in Dramais (1986), 
has been revised to incorporate two new member countries, Spain and Portugal, into the aggregate $\mathrm{EC}$ module, and includes improvements suggested by members of the EC "Experts Group" and professional economists. Similarly, the results from the U.S. and Japanese modules have been tested during the Seminar on Empirical Macroeconomics for Interdependent Economies, organized in March, 1986 by the Brookings Institution in Washington, D.C. (Bryant et. al. 1988). There, simulations from 12 multinational models were compared with reference to a common baseline. An analysis of U.S. and Japanese results showed that the Compact results were consistent with the "consensus" multipliers given by 9-10 models out of 12 (the major outliers being the Minford's model and Sim's Var model). Table 4, which contains a summary of the results, shows that Compact multipliers are in line with the multipliers of alternative models. This conclusion is confirmed by a survey on the effects of taxation in 18 economic models by Knoester and Kolodziejak (1992).

In Compact, taxes affect the economy in traditional and nontraditional ways. Tax increases depress demand, and hence output, in the traditional sense that they decrease disposable income. In addition, there is a nontraditional forward shifting effect; namely higher tax rates and/or higher social security contributions cause

Table 4. Comparison of fiscal policy multipliers of Compact and other multicountry models (simulation effect in percent point deviation from common baseline in second year of increase in government expenditure of 1 percent of GDP).

\begin{tabular}{|c|c|c|c|c|c|c|c|c|c|}
\hline & $Y$ & $\mathrm{CPI}$ & $\begin{array}{c}\mathrm{i} \\
\text { (pts.) }\end{array}$ & $\begin{array}{l}\text { currency } \\
\text { value }\end{array}$ & $\begin{array}{l}C A \\
(\$ b)\end{array}$ & $\begin{array}{l}C A^{*} \\
(\$ b)\end{array}$ & $\begin{array}{c}\mathrm{i}^{\star} \\
\text { (pts.) }\end{array}$ & $\mathrm{CPI}^{*}$ & $Y^{*}$ \\
\hline Standardized baseline & 2.8 & 3.6 & & $-2.5 \%$ & -88.5 & 44.7 & & 4.1 & 3.5 \\
\hline Fiscal expansion in U.S. & \multicolumn{5}{|c|}{ Effects in U.S. } & \multicolumn{4}{|c|}{ Effects in non-U.S. } \\
\hline MCM Multicountry & 1.8 & 0.4 & 1.7 & 2.8 & -16.5 & 8.9 & 0.4 & 0.4 & 0.7 \\
\hline EC Compact & 1.2 & 0.6 & 1.5 & 0.6 & -11.6 & 6.6 & 0.3 & 0.2 & 0.3 \\
\hline OECD Interlink & 1.1 & 0.6 & 1.7 & 0.4 & -14.2 & 11.4 & 0.7 & 0.3 & 0.4 \\
\hline LINK Project & 1.2 & 0.5 & 0.2 & 0.1 & -6.4 & 1.9 & NA & 0.0 & 0.1 \\
\hline Liverpool & 0.6 & 0.2 & 0.4 & 1.0 & -7.0 & 3.4 & 0.1 & 0.6 & 0.0 \\
\hline
\end{tabular}

Fiscal expansion in non-U.S. OECD Effects in non-U.S. OECD

Effects in U.S.

\begin{tabular}{lrlllrrrrr}
\hline MCM Multicountry & 1.4 & 0.3 & 0.6 & 0.3 & -7.2 & 7.9 & 0.5 & 0.2 & 0.5 \\
EC Compact & 1.3 & 0.8 & 0.4 & 0.6 & -9.3 & 3.0 & 0.0 & 0.1 & 0.2 \\
OECD Interlink & 1.5 & 0.7 & 1.9 & 0.9 & -6.9 & 3.3 & 0.3 & 0.2 & 0.1 \\
LINK Project & 1.2 & 0.1 & NA & 0.1 & -6.1 & 6.3 & 0.0 & 0.0 & 0.2 \\
Liverpool & 0.3 & 0.8 & 0.0 & 3.3 & -17.2 & 11.9 & 0.8 & 3.1 & 0.5 \\
\hline
\end{tabular}

Source: Frankel (1988). Deviations in percent or percent points from standardized baseline. $Y=G D P$, $\mathrm{CPI}=$ Consumers Price Index, inflation, $i=$ real short-term interest rate, $\mathrm{CA}=$ U.S. Current Account, $\mathrm{CA}^{*}=$ Current Account of non-U.S. OECD, i.e., japan, Germany, U.K., and Canada. The Federal Reserve Board Multicountry Model is described in Edison et al. (1986); the OECD Interlink Model, e.g., in OECD (1979b) and Richardson (1987); the Project Link, e.g., in Johnson and Klein (1974) and Hickman (1985); the Liverpool World Model in Minford, Agénor, and Nowell (1986). 
higher real wages. As explained in Knoester and Van der Windt (1987), the rationale for this behavior can be found in wage bargaining models in which employees bargain with employers, not for real income, but for real net income. The outcome is that employees will claim higher real wages in the event of increasing tax rates and/or social security contributions. This forward shifting of taxation has also been modeled in Compact by the inclusion of the net after-tax wage rate in the equation for the nominal wage costs. Dramais (1986) estimates that a fall in the purchasing power of the net after-tax wages by $1 \%$ will be followed by an increase of nominal wage costs by about $0.4 \%$ in the following year.

The forward shifting of taxation implies the inverted Haavelmo effect, which is the opposite of the Keynesian Haavelmo effect (Knoester 1983, 1991, 1993). The latter says that, as a consequence of a simultaneous increase of both public spending and taxes-i.e., by a balanced budget-the effects on income and employment would be positive (Haavelmo 1945). According to the inverted Haavelmo effect, the positive balanced-budget multiplier changes into a negative balanced-budget multiplier. The reason is that higher tax rates mean higher real wages, lower profits, and hence lower investments, less economic growth, and more unemployment. These negative effects of taxation more than offset the positive effects on the economy of the concomitant higher public spending. In reverse, the principle of the inverted Haavelmo effect implies that a simultaneous cut in public spending and taxation will lead to faster economic growth and less unemployment, thus providing a theoretical and empirical basis for supply-side policies. We will return to this issue in the next section.

\section{Individual fiscal policies}

Given the medium- and long-term growth scenarios discussed earlier, policymakers in Europe, Japan, and the United States will try to increase growth. At the same time these blocks have a common interest in diminishing their mutual trade imbalances. In this section we will discuss some fiscal policy options which, given these conditions, seem plausible when each of the three blocks acts on a purely individual level. This means that the three blocks will try to raise, or at least maintain, economic growth under the restriction of other economic policy goals, such as improving the external balance (e.g., diminishing the surpluses in the case of Japan) or decreasing the government budget deficit. In terms of game theory, the outcome will be a Nash solution, that is noncooperative (Nash 1950, Nash 1951, McMillan 1986).

The most plausible options for Europe to stimulate economic growth by fiscal policies are lower taxation with a higher budget deficit, and lower taxation with an ex ante simultaneous decrease in public spending, the latter combined with wage moderation. Table 5 shows the medium-term effects of such policies using Compact. It appears that only a tax reduction would result in more economic growth, more inflation, and less unemployment. Obviously, Compact shows, on balance, a Keynesian outcome. Yet, there are serious negative side effects, such as a higher 
Table 5. Effects of once-and-for-all fiscal policy measures taken by Europe alone.

\begin{tabular}{|c|c|c|c|c|c|c|}
\hline \multirow{2}{*}{$\frac{\text { Europe }^{\mathrm{a}}}{\text { Change in levels after year }}$} & \multicolumn{2}{|c|}{ Tax Reduction ${ }^{b}$} & \multicolumn{2}{|c|}{$\begin{array}{l}\text { Tax Reduction } \\
\text { and Public } \\
\text { Spending Cuts }\end{array}$} & \multicolumn{2}{|c|}{$\begin{array}{l}\text { Tax Reduction, } \\
\text { Public Spending } \\
\text { Cuts and Wage } \\
\text { Moderationd }^{\text {d }}\end{array}$} \\
\hline & 1 & 5 & 1 & 5 & 1 & 5 \\
\hline Real GDP (\%) & 0.20 & 0.47 & -0.54 & 0.13 & -0.80 & 0.43 \\
\hline GDP Deflator (\%) & 0.00 & 0.67 & -0.13 & -0.47 & -0.60 & -1.12 \\
\hline Unemployment Rate & -0.07 & -0.13 & 0.13 & -0.13 & 0.21 & -0.57 \\
\hline Budget Deficit ${ }^{c}(-)(\%$ GDP) & -0.60 & -0.40 & 0.00 & 0.07 & -0.08 & 0.21 \\
\hline Current Balance (\%GDP) & -0.07 & -0.26 & 0.13 & 0.00 & 0.21 & 0.01 \\
\hline
\end{tabular}

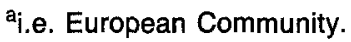

${ }^{b}$ Decrease in direct taxes by $1 \%$ of the wage bill.

'Simultaneous decrease in direct taxes and public spending by $1 \%$ of the wage bill.

${ }^{d}$ Simultaneous decrease in direct taxes and public spending and wages by $1 \%$ of the wage bill.

${ }^{\text {e}}$ Budget deficit of general government.

inflation rate, an increased budget deficit and, last but not least, a deterioration in the balance of payments. Note also that Compact certainly does not confirm the claim made by supply-side economics in its simplest form-and practiced by the Reagan administration in the early 1980s - that a tax rate reduction would enlarge the tax base so as to raise tax revenues. ${ }^{6}$ Compact simulations show that in the medium run only one-third of the original increase in the budget deficit can be reduced. This outcome for Europe seems to correspond remarkably with the American experience. According to Lindsey (1985), one-third of the tax cuts made by the Reagan administration in 1982 were "earned back." Thus, the American experience does not appear to be a good example for Europe to follow.

Even so, there is growing consensus in Europe that tax cuts may have positive supply-side effects on economic growth and employment. At the same time, it is recognized that such tax cuts should not be financed by increasing budget deficits; that is, tax cuts financed by a simultaneous cut in public spending. Knoester ( 1983 , $1988 \mathrm{a}, 1988 \mathrm{~b}, 1991,1993)$ argues that such a policy would boost economic growth and reduce unemployment through the inverted Haavelmo effect. Table 5 shows that, as a result of a simultaneous decrease in public spending and direct taxes, economic growth decreases in the short run. This means that the short-term findings of Compact confirm the Keynesian Haavelmo effect instead of the inverted Haavelmo effect. However, after a certain delay, these outcomes change completely. In the medium run, economic growth shows an increase instead of a decrease. Hence, Compact simulations are consistent with the thesis of the inverted Haavelmo effect, though only in the medium run and to a lesser extent than in Knoester (1983, 1988a, 1988b). ${ }^{7}$ Knoester and Kolodziejak (1992) compare taxation across 18 models and find that in Compact the cumulated effect of a once-and-for-all decrease in direct taxes of $1 \%$ of GDP, financed by a simultaneous decrease in public 
spending, results in the following time profile of Dutch production: $-0.7 \%$ after 1 year, $-0.2 \%$ after 3 years, and $0.6 \%$ after 5 years. In contrast, for all models examined, the average effect on production was $-0.2 \%, 0.0 \%$, and $0.4 \%$, respectively. The outcomes for the United States, the United Kingdom, Germany, and France were in line with the overall average effects. In any case, tax reductions financed by simultaneous public spending cuts seem to be a better alternative for Europe than tax cuts financed by increasing budget deficits because of favorable consequences on the inflation rate, the government budget deficit, and the balance of payments in combination with an increase in economic growth. Finally, it should be noted that the positive effect of this policy on the government budget deficit implies that the ex ante zero budgetary effects of this policy mix turn positive (ex post) in the medium run. This is caused by the enlarged tax base resulting from the increased economic growth.

A far better picture emerges even when the simultaneous decrease in public spending and direct taxes is accompanied by a corresponding wage moderation. Technically, wage moderation was simulated in the way put forward by Tinbergen in his 1936 presentation of the world's first empirical macroeconomic model. As discussed in Knoester and Wellink (1993), Tinbergen reacted with surprise to a question asking how the endogeneously modeled wage rate equation could be used for an autonomous wage decrease: "The trick is that, in that wage equation, the relationship which is assumed for wages is, for one moment, made inoperative and that, instead, it is assumed that wages show a decrease, independently of the forces acting on them." We have followed Tinbergen by expanding the wage rate equation with an autonomous shift variable bearing a coefficient of 1.0. The motivation for wage moderation can be found in wage bargaining models, where employees bargain for net real income. In European countries like The Netherlands, the offset between wage moderation and tax reduction is viewed rationally by the "social" partners-namely the government, employees, and employers. The benefits of this policy mix can be attractive for all three parties because employers are not confronted with increasing wage costs, employees will maintain their real net income, and government may benefit from the country's improved competitive position, inducing a broader tax base and less unemployment. An additional motivation for employees to moderate their wage claims is justified by the behavior of trade unions, especially in Europe and Japan, aimed at raising the medium- and long-term benefits of their members instead of focusing on short-term goals that may prove counterproductive in the longer term. The combination of tax reduction, public spending cuts, and wage moderation shows better outcomes than tax reductions without wage moderation. Better results are obtained for the unemployment rate, the government budget deficit, the balance of payments, the inflation rate, and economic growth. In judging these results it should be noted that possible overriding market forces that may diminish the initial positive effects of this policy mix are included in the Compact model ${ }^{8}$ Hence, for Europe, this policy mix seems the better alternative for restoring economic growth and lowering unemployment, given the specific European starting conditions for its current balance and its budget deficit. 
Japan has much greater fiscal opportunities for pursuing economic growth policies than Europe and the United States. Today, Japan has a large balance-ofpayments surplus and a small government budget deficit. In addition, Japanese public spending share of GDP is lower than in Europe and the United Statesabout $32 \%$ compared with about $52 \%$ and $38 \%$, respectively. ${ }^{9}$ Table 6 shows the results of stimulating fiscal policies for Japan. Attractive results in terms of economic growth are obtainable through tax reductions or higher public spending. The resulting deterioration in the current account would be modest compared with the present large surpluses and with the attendant gains in economic growth and unemployment. The simulations suggest that, for Japan, an increase in public spending that is financed initially by a higher budget deficit is the most growthpromoting policy option.

The primary interest of U.S. policymakers may not be so much to increase economic growth as to cut the government budget deficit and the current account deficit, preferably while maintaining economic growth or otherwise minimizing the negative growth effects. Table 7 shows that tax rate increases and public spending cuts would lower the American twin deficits at the expense of economic growth. A policy of tax rate increases may even saddle the U.S. economy with the additional problem that the higher rates may be shifted forward into higher wages (Knoester 1983, Knoester and Van der Windt 1987). Table 7 shows that, when tax increases lead to a forward shifting of taxation, the loss in economic growth and employment becomes worse. So the best option of the United States seems to be to curb the budget deficit through public spending cuts.

Table 6. Effects of once-and-for-all fiscal policy measures taken by Japan alone.

\begin{tabular}{|c|c|c|c|c|c|c|}
\hline \multirow{2}{*}{$\frac{\text { Japan }}{\text { Change in levels after year }}$} & \multicolumn{2}{|c|}{ Tax Reduction ${ }^{\mathrm{a}}$} & \multicolumn{2}{|c|}{$\begin{array}{l}\text { Tax Reduction } \\
\text { and Public } \\
\text { Spending Cuts }\end{array}$} & \multicolumn{2}{|c|}{$\begin{array}{c}\text { Increase in } \\
\text { Public Spending }\end{array}$} \\
\hline & 1 & 5 & 1 & 5 & 1 & 5 \\
\hline Real GDP (\%) & 0.26 & 0.36 & -0.46 & -0.43 & 0.73 & 0.80 \\
\hline GDP Deflator (\%) & 0.03 & 0.38 & -0.03 & 0.07 & 0.07 & 0.27 \\
\hline Unemployment Rate & -0.03 & -0.13 & 0.10 & -0.00 & -0.13 & -0.13 \\
\hline Budget Deficit $(-)^{d}(\% G D P)$ & -0.49 & -0.35 & 0.00 & -0.03 & -0.60 & -0.43 \\
\hline Current Balance (\%GDP) & -0.05 & -0.23 & 0.08 & -0.10 & -0.13 & -0.13 \\
\hline
\end{tabular}

aDecrease in direct taxes by $1 \%$ of the wage bill.

bSimultaneous decrease in direct taxes and public spending by $1 \%$ of the wage bill.

Increase in public spending by $1 \%$ of the wage bill.

${ }^{d}$ Budget deficit of general government. 
Table 7. Effects of once-and-for-all fiscal policy measures taken by the United States alone.

\begin{tabular}{lccrrrr}
\hline United States & \multicolumn{2}{c}{ Tax increases } & \multicolumn{2}{c}{$\begin{array}{c}\text { Tax Increase and } \\
\text { Wage Increase }\end{array}$} & \multicolumn{2}{c}{$\begin{array}{c}\text { Public Spending } \\
\text { Cuts }^{\mathrm{c}}\end{array}$} \\
\hline Change in levels after year & \multicolumn{1}{c}{1} & 5 & \multicolumn{1}{c}{5} & \multicolumn{1}{c}{5} & 1 & 5 \\
\hline Real GDP (\%) & -0.27 & -0.54 & 0.06 & -0.67 & -0.87 & -0.47 \\
GDP Deflator (\%) & -0.05 & -0.67 & 0.45 & -0.07 & -0.12 & -1.00 \\
Unemployment Rate & 0.08 & 0.40 & -0.02 & 0.47 & 0.35 & 0.53 \\
Budget Deficit (-) (\%GDP) & 0.54 & 0.46 & 0.64 & 0.40 & 0.47 & 0.39 \\
Current Balance (\%GDP) & 0.06 & 0.23 & -0.02 & 0.13 & 0.13 & 0.23 \\
\hline
\end{tabular}

ancrease in direct taxes by $1 \%$ of the wage bill.

'Simultaneous increase in direct taxes and wages by $1 \%$ of the wage bill.

'Decrease in public spending by $1 \%$ of the wage bill.

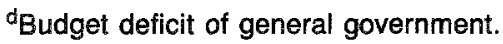

\section{Coordinated fiscal policies}

The individual fiscal actions of Europe, Japan, and the United States would, of course, have effects on each other. Therefore, we have quantified the effects of fiscal policy measures taken in each block, including the feedback effects on the other two blocks. The feedback effects of such "joint" or "coordinated actions" run through the international trade and capital linkages of Compact. A plausible policy mix for the 1990s follows from the above discussion of the most likely individual fiscal policy measures. Table 8 contains the results of this policy mix, consisting of a simultaneous reduction in wages, direct taxes, and public spending in Europe; an increase in public spending in Japan; and a decrease in public spending to cut the budget deficit in the United States. This policy mix would have the best effects on economic growth in Japan, while diminishing the Japanese current account surpluses. For Europe too, economic growth gains would be substantial,

Table 8. Effects of a joint action of Europe, Japan, and the United States.*

\begin{tabular}{lrrrrrr}
\hline & \multicolumn{2}{c}{ Europe $^{\mathrm{a}}$} & \multicolumn{2}{c}{ Japan } & \multicolumn{2}{c}{ United States } \\
\hline Change in levels after year & \multicolumn{1}{c}{1} & \multicolumn{1}{c}{5} & \multicolumn{1}{c}{1} & \multicolumn{1}{c}{5} & \multicolumn{1}{c}{1} & 5 \\
\hline Real GDP (\%) & -0.87 & 0.43 & -0.49 & 0.61 & -0.89 & -0.35 \\
GDP Deflator (\%) & -0.61 & -1.21 & 0.07 & 0.11 & -0.13 & -0.92 \\
Unemployment Rate & 0.25 & -0.50 & -0.09 & -0.05 & 0.35 & 0.43 \\
Budget Deficit (-) (\%GDP) & -0.08 & 0.14 & -0.61 & -0.50 & 0.53 & 0.29 \\
Current Balance (\%GDP) & 0.17 & -0.02 & -0.34 & -0.32 & 0.14 & 0.21 \\
\hline
\end{tabular}

*A simultaneous once-and-for-all decrease in wages, direct taxes, and public spending by $1 \%$ of the wage bill in Europe, an increase in public spending in Japan, and a decrease in public spendina in the United States.

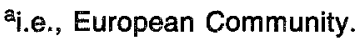


while improving the balance of payments in the short run. Economic growth would decline in the United States, whereas the twin deficits would diminish. Note that the best effects on unemployment would occur in Europe, while the best effects on the budget deficit and the balance of payments would occur in the United States. These different outcomes are, of course, mainly due to the chosen composition of the policy mix, which in turn is the result of the specific starting positions of the three blocks. Alternative policy mixes are possible, of course.

An example of an alternative coordinated action is presented in Table 9: the three blocks pursue a policy of tax reduction and wage moderation. In The Netherlands this policy mix became well known as the Schouten Scenario (Schouten 1982, 1986). The key element in substituting wage moderation for tax reduction is that the government offers tax reductions to employees and employers in exchange for wage moderation. Such a "swap" could be formalized in the form of a social covenant among the parties. The simulations show a substantial increase in economic growth in the three blocks, albeit at the expense of higher budget deficits and with virtually unchanged external imbalances. It should be emphasized that, in the medium run, the "earn-back" effects of this joint action would be substantial. In Europe and Japan, the enlarged tax base would be about two-thirds of the initial increase in the budget deficit, and in the United States it would be about $50 \%$.

Finally, Table 10 shows another policy scenario: wage moderation and tax reduction in Europe, a tax reduction in Japan, and a U.S. increase in taxes and wages. The fact that this time there is no simultaneous wage moderation in Japan implies for this country smaller effects on economic growth, smaller reductions in unemployment, and a larger budget deficit. However, compared with the previous joint action, a current account deficit now results for Japan, which is in line with the goals of international policy coordination. In addition, European economic growth is negatively influenced by lower foreign growth resulting from lack of wage moderation in Japan and the United States. Although the Schouten Scenario still leads on balance to higher economic growth in Europe, the latter is now accompanied by a larger increase in the budget deficit. For the United States, the results are less favorable compared with the Schouten Scenario in Table 9, although they differ only slightly from the mix presented in Table 8.

Table 9. Effects of a joint action by Europe, Japan, and the United States: a once-and-for-all simultaneous tax reduction and wage moderation.*

\begin{tabular}{lrrrrrr}
\hline & \multicolumn{2}{c}{ Europe $^{\mathrm{a}}$} & \multicolumn{2}{c}{ Japan } & \multicolumn{2}{c}{ United States } \\
\hline Change in levels after year & \multicolumn{1}{c}{1} & 5 & 1 & 5 & 1 & 5 \\
\hline Real GDP (\%) & -0.07 & 0.94 & -0.02 & 0.78 & -0.04 & 0.85 \\
GDP Deflator (\%) & -0.47 & 0.13 & -0.52 & -0.60 & -0.44 & 0.08 \\
Unemployment Rate & 0.01 & -0.67 & 0.01 & -0.23 & 0.02 & -0.69 \\
Budget Deficit (-) (\%GDP) & -0.68 & -0.22 & -0.59 & -0.18 & -0.64 & -0.30 \\
Current Balance (\%GDP) & 0.00 & -0.15 & -0.02 & 0.12 & 0.01 & 0.04 \\
\hline
\end{tabular}

*Amounting to $1 \%$ of the wage bill.

ai.e., European Community. 
Table 10. Effects of a joint action by Europe, Japan, and the United States: a once-and-for-all simultaneous wage moderation and tax reduction in Europe, increase in wages and taxes in the United States, and tax reduction in Japan.*

\begin{tabular}{lrrrrrrr}
\hline & \multicolumn{2}{c}{ Europe $^{\text {a }}$} & \multicolumn{2}{c}{ Japan } & \multicolumn{2}{c}{ United States } \\
\hline Change in levels after year & \multicolumn{1}{c}{1} & \multicolumn{1}{c}{5} & \multicolumn{1}{c}{1} & 5 & 1 & 5 \\
\hline Real GDP (\%) & -0.09 & 0.62 & 0.18 & 0.17 & 0.11 & -0.49 \\
GDP Deflator (\%) & -0.47 & 0.12 & 0.03 & 0.18 & 0.44 & 0.10 \\
Unemployment Rate & 0.02 & -0.46 & -0.03 & -0.04 & 0.04 & 0.36 \\
Budget Deficit (-) (\%GDP) & -0.67 & -0.30 & -0.54 & -0.47 & 0.69 & 0.38 \\
Current Balance (\%GDP) & 0.00 & -0.15 & -0.10 & -0.13 & 0.01 & 0.10 \\
\hline
\end{tabular}

${ }^{*}$ Amounting to $1 \%$ of the wage bill.

ai.e., European Community.

For a proper assessment of the results reported in this section it should be noted that in Compact public spending is treated as a pure consumption good that is substitutable with private consumption. However, the concomitant negative income effects of public spending cuts do not influence the labor supply behavior, as a result of which, for example, the labor supply could rise and wages could fall further. Yet, this labor supply behavior does not imply a serious bias for the results of the policy simulations. This is so because the negative income effects of public spending cuts will be outweighed by the positive income effects of the simultaneously pursued tax reductions. It should be emphasized that the above results should certainly not be interpreted as offering a free lunch for OECD governments. First of all, both Europe and the United States have to cut public spending in order to achieve a better economic performance in the 1990s. This is a difficult task for policymakers because past experience has shown that politicians and the public are unwilling to make such public spending cuts for favorable future effects that they regard to be uncertain. More economic growth and a reduction of current account imbalances in the OECD area, however, remain essential to long-run economic performance. And this simple truth should be the incentive for OECD governments to pursue the suggested international policy coordination. Such policies could prevent our children and grandchildren from being confronted with more draconian public spending cuts.

\section{Concluding Remarks}

It is of great importance for Europe, the United States, and Japan to restore economic growth to levels that occurred before the first oil crisis of 1973-1974. However, at the same time these leading blocks of the world economy have to reduce the existing and projected trade imbalances. Otherwise, increasing protectionism and volatile exchange rate movements will pose a serious threat to the world's economic prospects in the 1990s, as well as to harmonious political relations. Hence, there is a need for improved economic policy coordination among 
Europe, the United States, and Japan in the 1990s. In this article we have analyzed some plausible coordinated fiscal policy actions of the world's three leading economic blocks, concentrating on different mixes of fiscal policies. Our main conclusions can be summarized as follows:

- For Europe, the most plausible fiscal policy option for the 1990 s seems to be a combination of lower direct taxes, public spending cuts, and wage moderation. This policy mix will produce higher economic growth and less unemployment, while the external imbalance and the government budget deficit remain unchanged or even show a slight improvement.

- For Japan, the degrees of freedom enjoyed by fiscal authorities are much greater than in Europe and in the United States. An expansionary Japanese fiscal policy-either through lower direct tax rates or higher public spending-therefore seems a plausible option for the 1990 s. This policy would boost economic growth and diminish Japan's current account surpluses.

- For the United States, public spending cuts or tax increases are necessary conditions for achieving the desired reduction in the twin deficits. Such a policy, however, would entail a lower rate of economic growth.

- Under a coordinated fiscal policy action, the benefits for economic growth would be larger in Europe and Japan than those obtained by uncoordinated actions. For the United States, the improvement in the twin deficits would be substantial.

- A joint action of tax reduction and wage moderation would further raise economic growth. Our analysis suggests that in the medium run the earn-back effects of this policy mix would vary between two-thirds and one-half of the initial increase in the government budget deficit. Although attractive in terms of economic growth, this type of collaborative action would not diminish the trade imbalances among the three blocks.

- The suggested policies should not be interpreted as offering a free lunch for OECD governments. Their policymakers face a difficult task to implement corrective actions, because the public, especially in the United States and Europe, regard the benefits from these actions as uncertain. Yet, without such actions our children and grandchildren will face larger public spending cuts.

\section{Acknowledgments}

We gratefully acknowledge the kind help given by André Dramais, who provided us with Compact model simulations. Of course, we are responsible for any remaining errors. We would also like to thank an anonymous referee and Michele Fratianni for their valuable comments on early drafts of this article.

\section{Notes}

1. See also Butler (1992).

2. For a general theoretical framework, see Tinbergen (1954, especially chapters 6-8). A brief comment is given in Molle (1990) and Kol and de Wolff (1993). 
3. For simulation purposes, specific software has been developed by Dramais to simplify the use of Compact by macroeconomists (Dramais 1986a).

4. The EC module is somewhat stylized because the introduction of institutional constraints and national specifics must wait for the development of national models with monetary sectors under the EC QUEST and HERMES projects.

5. The estimation is done on yearly data using primarily the EC aggregate series published in the Statistical annex of the "Annual Economic Review" (European Economy, November issue). The sources for the series are Eurostat and Commission Services.

6. See Laffer (1980) and Feldstein (1986) who criticizes what he calls "supply-side extremists."

7. The reason for these different quantitative outcomes is that-contrary to Knoester $(1983,1988 \mathrm{a}$, 1988b, 1991, 1993) -the wage equation of Compact does not include an explicit but an implicit forward shifting of higher taxes into higher wages.

8. Such an overriding market force is, for example, the Philips curve mechanism included in Com. pact. If the unemployment rate should decrease as a result of the suggested substitution between wage moderation and tax reduction, wage claims would increase in the second instance. Our simulations with Compact suggest, however, that the effects of these market forces are certainly not strong enough to compensate for or to undo the positive effects of this policy mix.

9. Shares for 1993 are based on the European Economy Statistical Annexes of the European Commission.

\section{References}

Andriessen, F. (1991) Japan/EC Relations and their Global Impact, Speech at the Fifth Annual EGJapan journalists' Conference, November 1991, Osaka.

Bremer, S.A. (ed) (1987) The GLOBUS-MODEL-Computer Simulation of Worldwide Political and Economic Developments. Frankfurt: Wissenschaftszentrum Berlin für Sozialforschung.

Bryant, R. and R. Portes (1987) Global Macroeconomics, Policy Conflict and Cooperation. London: Bryant, R.C. et al. (eds) (1988) Empirical Economics for Interdependent Economies. Washington, DC: Brookings Institute.

Butler, A. (1992) "Should We Attempt to Eliminate the U.S.-Japan Trade Deficit?" International Economic Conditions, Federal Reserve Bank of St. Louis.

Canzoneri, M. and P. Minford (1988) "Policy Interdependence: Does Strategic Behavior Pay? An Empirical Investigation Using the Liverpool World Model." In D.R. Hogdeman and G. Wood (eds), Macroeconomic Policy and Economic Interdependence. New York: Macmillan.

Central Planning Bureau (1991) "The European Economy, Medium-Term Perspective," CPB Working Paper No. 39, The Hague.

Commission of the European Communities (1990) Annual Economic Report 1990-91, "The European Community in the 1990s: Towards Economic and Monetary Union," European Economy 46, December.

Cooper, R.N. (1985) "Economic Interdependence and Coordination of Economic Policies." In Ronald W. Jones and Peter B. Kenen (eds), Handbook of International Economics, vol. 2. Amsterdam/New York: North Holland.

Currie, D. and J. Whitley (1993) "The Global Implications of Deficit Adjustment in the G7 Countries," International Economic Outlook, 1, 14-21.

Dramais, A. (1986) "Compact-a Prototype Macroeconomic Model of the European Community in the World Economy," European Economy 27, 111-160.

Dramais, A. (1986a) "Compact Users Guide," Directorate-General for Economic and Financial Affairs, Brussels: Commission of the European Communities.

Dramais, A. (1987) New Developments of the COMPACT model since October 1985. Directorate-General for Economic and Financial Affairs, Brussels: Commission of the European Communities. 
Edison, H. et al. (1986). "The Structure and Properties of the FRB Multicountry Model," International Finance Discussion Papers No. 293, Washington, DC.

Feldstein, M. (1986) "Supply-Side Economics: Old Truths and New Claims," American Economic Review 76, 26-30.

Feldstein, M. (1987) "Rethinking International Economic Coordination," Lecture at the 50th Anniversary of Nuffield College, Oxford, October 23.

Feldstein, M. (1988) Distinguished Lecture on Economics in Government, "Thinking about International Economic Coordination," Journal of Economic Perspectives 2, 3-13.

Fieleke, N. (1988) "Economic Interdependence between Nations: Reason for Policy Coordination?" New England Economic Review May/June, 21-38.

Frankel, J. (1988) "Obstacles to International Macroeconomic Policy Coordination," Princeton Studies in International Finance, 64, Princeton: Princeton University Press.

Frankel, J. and K. Rockett (1988) "International Macroeconomic Policy Coordination When Policymakers Do Not Agree on the True Model," American Economic Review 78, 318-340.

Frenkel, J., M. Goldstein and P. Masson (1989) "Simulating the Effects of Some Simple Coordinated versus Uncoordinated Policy Rules." In Ralph A. Bryant et al. (eds), Macroeconomics Policies in an Interdependent World. Washington, DC: International Monetary Fund, pp.. 203-239.

Ghosh, A.R. and P. Masson (1993) Economic Cooperation in an Uncertain World. Oxford: Basil Blackwell. Haavelmo, T. (1945). "Multiplier Effects of a Balanced Budget," Econometrica 13, 311-318.

Hickman, B. and L. Klein (1985) "Recent Developments in Project LINK," ITEMS, Social Science Research Council.

Hooper, P. and J. Marquez (1993) "Exchange Rates, Prices, and External Adjustment in the United States and Japan," International Finance Discussion Papers 456, Washington, DC: Board of Governors of the Federal Reserve System.

International Monetary Fund (1992) World Economic Outlook, Washington, DC: IMF.

International Monetary Fund (1993) "Ministers Call for Global Cooperation to Strengthen Growth Prospects," IMF Survey, May 17, 145.

International Monetary Fund (1993a) Direction of Trade Statistics Yearbook 1993 and September 1993 issue. Washington, DC: IMF.

Johnson, K. and L. Klein (1974) "LINK Model Simulations of International Trade: An Evaluation of the Effects of Currency Realignment," Journal of Finance, 617-630.

Keizai Koho Center (1989) Japan 1990: An International Comparison, Tokyo.

Knoester, A. (1983) "Stagnation and the Inverted Haavelmo Effect: Some International Evidence," De Economist 131, 548-584.

Knoester, A. (1988a) "Supply-Side Policies in four OECD Countries." In H. Motamen (ed), Economic Modelling in the OECD Countries, London: Chapmann \& Hall.

Knoester, A. (1988b) "The Haavelmo Effect Revisited," Finnish Economic Papers 1, 121-125.

Knoester, A. (1991) "Supply-Side Economics and the Inverted Haavelmo Effect." in E.S. Phelps (ed), Recent Developments in Macroeconomics, The International Library of Critical Writings in Economics 13, Aldershot/Brookfield: Edward Elgar Publishing Limited.

Knoester, A. (1993) "The Inverted Haavelmo Effect and the Effects of Fiscal Policies in the United States, the United Kingdom, Germany and The Netherlands." In A. Knoester (ed), Taxation in the United States and Europe: Theory and Practice. London/New York: Macmillan/St. Martins Press.

Knoester, A. and A. Kolodziejak (1988) "Economic Growth in Europe, Japan, and the United States: Policy Options for the 1990s," Research Memorandum 8804, University of Nijmegen, Institute of Economics, Nijmegen, 1-24.

Knoester, A. and A. Kolodziejak (1992) "Effects of Taxation in Economic Models: A Survey," Economic Modelling 9, 352-364.

Knoester, A., A. Kolodziejak, and A. Muijzers (1989) "Gaandeweg tot de Europese orde geroepen" (Gradually Called to European Order). In P. de Grauwe, A. Knoester, A. Kolodziejak, A. Muijzers, F. van der Ploeg, D.J. Rijnvos, De Europese monetaire integratie: vier visies (European Monetary Integration: Four Views), Report V66. The Hague: Scientific Council for Government Policies. 
Knoester, A., A. Kolodziejak, and A. Muijzers (1990) "Economic Policy and European Integration," Research Memorandum 9001, University of Nijmegen, Department of Applied Economics, Nijmegen, $1-62$.

Knoester, A. and N. van der Windt (1987) "Real Wages and Taxation in Ten OECD Countries," OXford Bulletin of Economics and Statistics 49, 151-169.

Knoester, A. and A.H.E.M. Wellink (1993) "Tinbergen and the Royal Netherlands Economic Association." In A. Knoester and A.H.E.M. Wellink (eds), Tinbergen Lectures on Economic Policy, Amsterdam, North-Holland.

Kol, J. and P. de Wolff (1993) "Tinbergen's Work: Change and Continuity." In A. Knoester and A.H.E.M. Wellink (eds), Tinbergen Lectures on Economic Policy, Amsterdam: North-Holland, 27-54.

Kolodziejak, A. (1986) "Policy-Mania and Policy-Resistance in Economics: Preparing a Model for Economic Policy of the European Community," mimeo, Luxembourg.

Laffer, A.B. (1980) "The Ellips, an Explanation of the Laffer Curve in a Twofactor Model." California. Leontief, W., A.P. Carter, and P. Petri (1977) The Future of the World Economy. New York: Oxford University Press.

Lindsey, L.B. (1985) "Taxpayer Behavior and the Distribution of the 1982 Tax Cut," Working Paper No. 1760, National Bureau of Economic Research, Cambridge, MA.

McKibbin, W. and J. Sachs (1988) "Coordination of Monetary and Fiscal Policies in the OECD." In Jacob A. Frenkel (ed), International Aspects of Fiscal Policy. Chicago: University of Chicago Press.

McMillan, J. (1986) Game Theory in International Economics, Chur: Harwood International Publishers, 2-28.

Minford, P., P.R. Agénor, and E. Nowell (1986) "A New Classical Econometric Model of the World Economy," Economic Modelling 3, 154-174.

MIT (1977) Energy: Global Prospect, 1985-2000. Report of the Workshop on Alternative Energy Strategies. Cambridge: MIT.

Molle, W. (1990). The Economics of European Integration (Theory, Practice, Policy). Dartmouth: Aldershot.

Nash, J.F. (1950) "The Bargaining Problem," Econometrica 18, 155-162.

Nash, J.F. (1951) "Non-cooperative Games," Annals of Mathematics 54, 286-295.

OECD (1978) Public Expenditure Trends. Paris: OECD.

OECD (1979a) Facing the Future: Mastering the Probable and Managing the Unpredictable. Paris: OECD.

OECD (1979b) "The OECD International Linkage Model," Economic Outlook: Occasional Studies. Paris: OECD.

OECD (1987) Interdependence and Cooperation in Tomorrow's World. A Symposium Marking the 25th Anniversary of the OECD. Paris: OECD.

OECD (1992) Economic Outlook No. 51. Paris: OECD.

Okawara, Y. (1991) "Japan-U.S. Relations in the Changing World," Japan and the World Economy $3,215-220$.

Onishi, A. (1986) "North-South Interdependence: Projection of the World Economy, 1985-2000," Center for Global Modeling, Journal of Policy Modeling 8, 181-198.

Onishi, A. (1988) "Projections of the OECD Economies in the Global perspective 1986-2000: Policy Simulations by the FUGI Global Macroeconomic Model." In H. Motamen (ed), Economic Modelling in the OECD Countries. London: Chapman \& Hall.

Oudiz, G. and J. Sachs (1984) "Macroeconomic Policy Coordination Among the Indusrial Economies," Brookings Papers on Economic Activity: Washington, DC: The Brookings Institution.

Richardson, P. (1987) "A Review of Recent Development in OECD's International Macroeconomic Model," OECD ESD Working Paper No. 46, Paris.

Schouten, D. (1964) "Een voorstel tot Europese looncoördinatie" (A. Proposal for European Coordination of Wages), Maandschrift Economie, 505-511.

Schouten, D. (1982) "Gelijktijdige en volgtijdelijke strijdigheid van doelstellingen" (Simultaneous and Chronological Conflict of Objectives), Royal Netherlands Academy of Sciences, Afd. Letterkunde, Nieuwe Reeks, deel 45, nr. 5.

Schouten, D. (1986) Het wankele evenwicht in de economie (Coordination versus Fragmentation of National and International Economic Policies). Leiden/Antwerpen; Stenfert Kroese BV. 
SEO (1991) Club Hermes: Perspectives èconomiques pour l'Europe 1991-1995, SEO-rapport nr. 277, Amsterdam.

Shishido, S. (1983) "Long-term Forecasts and Policy Implications: Simulations with a World Econometric Model (T-FAIS IV)" University of Tsukuba-Foundation for the Advancement of International Science. In S.G. Hickman (ed), Global International Economic Mode/s. Amsterdam, North-Holland, pp. 53-68. ten Brink, N. (1988) Tracing Global Implications of Europe 1992 with the GLOBUS-MODEL, mimeo, University of Nijmegen, Nijmegen.

Tinbergen, J. (1954) International Economic Integration, Amsterdam: North-Holland.

van Agt, A.A.M. (1990) "United States-Japan-Europe: the Unholy Trinity," European Affairs 2, 61-65. Vaubel, R. (1983) "Coordination or Competition Among National Macroeconomic Policies?" In F. Machlup et al. (eds), Reflections on a Troubled World Economy. London: Macmillan, pp. 3-28. World Bank (1987) World Development Report. New York: Oxford University Press. 